\author{
DANIEl Szostak \\ Uniwersytet Szczeciński, Polska \\ University of Szczecin, Poland
}

\title{
Planowanie rozwoju lokalnego jako samorządowe narzędzie kształtowania funkcii usługowej gminy Moryń
}

\section{Local Development Planning as a Local Government Tool for Shaping the Service Function of the Moryń Commune (Poland)}

\begin{abstract}
Streszczenie: Artykuł zawiera przegląd zagadnień dotyczących problematyki planowania rozwoju funkcji usługowej na poziomie lokalnym, ze szczególnym uwzględnieniem opracowywania i wdrażania lokalnej strategii rozwoju gminy na przykładzie gminy Moryń. Pokazano korzyści, jakie daje lokalnej gospodarce opracowanie strategii rozwoju funkcji usługowej, oraz wskazano kierunki działania strategicznego na podstawie inwentaryzacji dostępnych zasobów endogenicznych. Ponadto pokazano, jak analizowana gmina drogą ewolucji i przemian strategicznych z realizacji funkcji rolniczej poprzez funkcję rolniczo-usługową przeszła do realizacji funkcji usługowej w dziedzinie turystyki. Badania przeprowadzone na potrzeby niniejszego artykułu stanowią uzupełnienie podobnych badań prowadzonych w innych gminach województwa zachodniopomorskiego oraz w całej Polsce. Problematyka badań nad rozwojem funkcji usługowej dla konkretnej gminy oraz przygotowana na jej potrzeby inwentaryzacja zasobów endogenicznych mają charakter unikatowy i oryginalny.
\end{abstract}

\begin{abstract}
The study provides an overview of issues related to the development of the service function development problem at the local level, with particular emphasis on issues related to the development and implementation of a local development strategy based on the example of the Moryn commune (Poland). The benefits of the development of the service function's development strategy for the local economy are shown, as well as the directions of strategic action based on the inventory of available endogenous resources. In addition, it shows how the analysed commune, through evolution and strategic changes from the implementation of the agricultural function through the agricultural and service function, has moved to the service function in the field of tourism. Research carried out for the purposes of preparing this presentation and the article on its basis is a supplement to similar research conducted in other communes of the Zachodniopomorskie Voivodeship and throughout Poland. The research on the development of the service function for a given commune and the inventory of endogenous resources prepared for its needs are unique and original.
\end{abstract}

Słowa kluczowe: gmina; planowanie; rozwój lokalny; strategia; turystyka; usługi Keywords: community; local development; planning; service; strategy; tourism 
Otrzymano: 18 grudnia 2018

Received: 18 December 2018

Zaakceptowano: 30 kwietnia 2019

Accepted: 30 April 2019

\section{Sugerowana cytacja / Suggested citation:}

Szostak, D. (2019). Planowanie rozwoju lokalnego jako samorządowe narzędzie kształtowania funkcji usługowej gminy Moryń. Prace Komisji Geografii Przemysłu Polskiego Towarzystwa Geograficznego, 33(2), 95-110. doi: 10.24917/20801653.332.7

\section{WSTĘP}

Jednym z najważniejszych zadań samorządu gminy jest zaspokajanie potrzeb lokalnej społeczności. Z jednej strony odpowiada on za wszystkie sprawy publiczne dotyczące życia mieszkańców w obrębie jednostki terytorialnej, a z drugiej - powinien stwarzać możliwości ukierunkowanego rozwoju zarządzanej przestrzeni (np. wspieranie innych funkcji, w tym usługowych) przez kreowanie niezbędnej infrastruktury społeczno-gospodarczej lub przez podejmowanie działań w celu zagospodarowania posiadanych zasobów endogenicznych (np. przyrodniczych), jak i wykorzystania kompetencji samych mieszkańców (np. proprzedsiębiorczych) (Witkowski, Starościc, 2008: 177).

W tym drugim przypadku władze samorządowe nie świadczą konkretnych usług komercyjnych, ale przyczyniają się do umożliwienia podmiotom prywatnym świadczenia, najczęściej w postaci komercyjnej, określonych usług niezbędnych na rynku i takich, na które jest aktualnie zapotrzebowanie. Usługi te z kolei kreują miejsca pracy, przynoszą dochody świadczącym owe usługi oraz warunkują rozwój innych usług na terenie gminy i realizację funkcji usługowej danej przestrzeni. Gmina może wtedy prowadzić takie działania, jak: promowanie, zagospodarowywanie zasobów, modernizacja infrastruktury społeczno-gospodarczej, pozyskiwanie środków zewnętrznych niezbędnych do powstania konkretnego rodzaju infrastruktury, planowanie rozwoju danej przestrzeni, inicjowanie działań zwiększających lokalną przedsiębiorczość mieszkańców itp.

Przykładowo wiele gmin nie świadczy usług noclegowych, ale podejmuje inicjatywy, aby pozyskać inwestorów hotelowych m.in. poprzez stwarzanie im przyjaznych warunków inwestycyjnych, oferowanie atrakcyjnych terenów pod konkretne inwestycje lub też dzięki opracowaniu funkcjonalnego planu rozwoju oferty substytucyjnej (np. agroturystycznej). Gmina może pozyskiwać również środki unijne na rozwój infrastruktury turystycznej, rekreacyjnej czy sportowej, które podnoszą w oczach inwestorów oraz samych turystów atrakcyjność turystyczną miejscowości, czego przykładem jest budowa ścieżek rowerowych, zagospodarowywanie brzegów jezior i rzek, budowa hal widowiskowo-sportowych, muzeów, centrów sportowo-rekreacyjnych, tworzenie infrastruktury niskoemisyjnej itp.

Realizacja określonej funkcji, np. usługowej, bardzo często warunkowana jest dostępem do niezbędnej infrastruktury społeczno-gospodarczej, za której tworzenie i utrzymanie nie odpowiadają zainteresowani eksploatacją mieszkańcy czy przedsiębiorcy. W związku z tym zaczynają pojawiać się negatywne relacje. Dla przykładu w danej gminie nie ma turystów, gdyż ta mimo posiadanych zasobów naturalnych nie jest w stanie ich właściwie zagospodarować, tj. brakuje odpowiedniej liczby miejsc gastronomicznych czy noclegowych. Z kolei inwestorzy nie inwestują $w$ danej gminie lub 
mieszkańcy nie podejmują aktywności gospodarczej, gdyż nie widzą w tym zasadności ekonomicznej (brak potencjalnych nabywców oferowanych usług).

Jak pokazuje praktyka, w wielu gminach funkcja usługowa (w wymiarze gospodarczym i komercyjnym najczęściej realizowana poprzez turystykę) może mieć i zazwyczaj ma charakter wiodący lub uzupełniający inne funkcje gospodarcze realizowane na danym obszarze (np. funkcje rolnicze przez rozwój usług agroturystycznych i turystycznych na bazie już istniejącej infrastruktury rolnej - budynki rolne przystosowywano m.in. do świadczenia usług noclegowych; funkcje przemysłowe przez rozwój i rozbudowę infrastruktury niezbędnej do świadczenia usług turystycznych, rekreacyjnych czy uzdrowiskowych).

Rozwój funkcji usługowej danego obszaru (gminy, powiatu, województwa) wiąże się przede wszystkim z wykorzystaniem do celów gospodarczych posiadanego potencjału endogenicznego, zarówno w aspekcie historycznym (np. na podstawie dotychczasowej specyfiki gospodarczej i społecznej danego obszaru, dzięki realizacji ukierunkowanego procesu inwestycyjnego, zastanego stanu infrastrukturalnego, dotychczasowych koncepcji rozwoju), jak i przyszłościowym (najczęściej na podstawie nowych kierunków rozwoju, które albo określają nowy kierunek, który uzupełnia dotychczasowy rozwój, albo wynikają z ewolucyjnych zmian zachodzących na danym obszarze, np. przejście od jednego sektora do innego, bardziej efektywnego). Widoczne to jest, gdy m.in. analizowane są kolejne strategie rozwoju społeczno-gospodarczego dla danego obszaru.

W wielu przypadkach przy opracowywaniu kolejnych strategii rozwój opiera się na nowych założeniach, zgodnie z którymi gospodarcza funkcja usługowa jest coraz bardziej dominująca i wiodąca. Nie oznacza to, że realizowane wcześniej funkcje zanikły (np. przemysłowe czy rolnicze). Wielokrotnie jest tak, że poprzednie funkcje nadal są realizowane, ale dana struktura gospodarcza jest już optymalnie ukształtowana i nie podlega istotnym przemianom. Jednocześnie władze samorządowe dochodzą do wniosku, że niezbędne jest znalezienie nowych kierunków rozwoju, które jeszcze lepiej przyczynią się do wykorzystania posiadanych zasobów endogenicznych.

Jednym z takich sektorów gospodarczych, który w coraz większym stopniu znajduje się w obszarze zainteresowania lokalnych samorządów, jest gospodarka turystyczna. Rozwój turystyki i związanej z nią infrastruktury usługowej (np. noclegowej, rekreacyjnej, gastronomicznej, logistycznej, obsługującej turystów) stanowi od wielu lat jedno z najważniejszych zagadnień rozwojowych polityki społeczno-gospodarczej władz różnego szczebla, od krajowego przez regionalny, aż po lokalny, w szczególności gminny. Powodem tego jest fakt, że coraz częściej turystyka traktowana jest jako ważny czynnik lokalnego rozwoju społeczno-gospodarczego (turystyka jako ważne lub główne miejsce pracy lokalnej społeczności, jako przestrzeń do komercjalizacji poprzez przedsiębiorczość pomysłów biznesowych, jako źródło przychodów budżetowych, jako ukierunkowany rozwój). Coraz częściej dotyczy to także obszarów, na których turystyka dotychczas nie odgrywała istotnej roli, zwłaszcza gospodarczej (w przestrzeni tychże gmin dominowały inne formy gospodarowania i aktywności gospodarczej, w tym zarobkowej, które były kształtowane i rozwijane od lat).

Wzrost znaczenia ruchu turystycznego oraz intensywny rozwój wielu lokalnych destynacji turystycznych spowodował, że turystykę traktuje się jako jedno z głównych narzędzi rozwoju gospodarczego, w tym usługowego na szczeblu lokalnym, przede wszystkim gminnym i powiatowym. Dotyczy to zwłaszcza obszarów, które wcześniej 
miały np. charakter rolniczy, a obecnie borykają się z problemami strukturalnego bezrobocia, szukają sposobów na aktywizację gospodarczą, kreowanie nowych miejsc pracy itp. Często w tych przypadkach industrializacja ze względu na lokalizację lub brak surowców jest utrudniona, a inne formy aktywności gospodarczej są nieopłacalne. Rozwój musi się opierać na posiadanych zasobach endogenicznych, głównie przyrodniczych, naturalnych, których jedynym sposobem zagospodarowania jest turystyka i związane z nią usługi (Głąbiński, Duda, Szostak, 2017).

W związku z tymi uwarunkowaniami do badania wybrano gminę Moryń (województwo zachodniopomorskie, powiat gryfiński). Celem artykułu jest wskazanie roli i miejsca planowania strategicznego w tworzeniu i rozwijaniu potencjału usługowego gminy w oparciu o turystykę, ze szczególnym uwzględnieniem rozwoju gminy Moryń. Hipoteza badawcza brzmi następująco: najskuteczniejszym narzędziem kształtowania funkcji usługowej gminy jest aktywne stosowanie narzędzia planowania rozwoju, jakim jest strategia rozwoju lokalnego. Dlatego też celem niniejszego artykułu jest udowodnienie postawionej tezy na przykładzie funkcjonowania jednej z gmin leżących w województwie zachodniopomorskim. Do analizy wybrano usługową funkcję turystyczną, kształtowaną za pomocą opracowanej i wdrażanej w życie strategii rozwoju.

\section{USŁUGI TURYSTYCZNE JAKO CZYNNIK I NARZĘDZIE ROZWOJOWE LOKALNEJ GOSPODARKI}

Usługi, w tym usługi turystyczne, stanowią w wielu krajach, a zwłaszcza w wymiarze lokalnym, dominujący obszar działalności gospodarczej, przejawiającej się zazwyczaj w postaci potrzeby planowania ukierunkowanego rozwoju (Tokarz, 2003: 5). Rozwój lokalnego sektora usług następuje pod wpływem wielu czynników, będących konsekwencją zmian demograficznych, społecznych, gospodarczych i politycznych.

Jak zauważają eksperci, w światowej gospodarce odnotowuje się dynamiczny rozwój turystyki jako sektora usługowego wielu gospodarek lokalnych, w którym rośnie liczba odwiedzających i turystów (przede wszystkim w celach turystycznych), a w związku z tym wzrasta liczba miejsc pracy, zarówno w skali globalnej, jak i lokalnej. Dlatego też turystyka jest niejednokrotnie traktowana nie tylko jako element składowy lokalnych gospodarek, gdzie tworzy się i sprzedaje usługowy produkt turystyczny, ale również istotny jest czynnik lokalnego rozwoju społeczno-gospodarczego, który coraz częściej brany jest pod uwagę przy opracowywaniu i realizacji lokalnych strategii rozwoju (Rapacz, Jaremen, 2009: 211).

Zależność lokalnych jednostek samorządu terytorialnego (gmin, powiatów) od turystyki i rozwoju usługowej gospodarki turystycznej jest tym większa, im wyższy jest poziom atrakcyjności turystycznej danego obszaru. Na atrakcyjność turystyczną składają się przede wszystkim: występowanie na danym terenie walorów oraz jakość i pojemność infrastruktury turystycznej i paraturystycznej. W przypadku wielu gmin i powiatów turystyka staje się coraz częściej istotną dziedziną lokalnej gospodarki, a przez to staje się akceleratorem rozwoju lokalnego.

Praktycznym obrazem takiego stanu jest to, że obok infrastruktury typowo turystycznej (np. baza noclegowa) dzięki turystyce rozwijają się inne dziedziny lokalnej gospodarki, jak handel, usługi towarzyszące i uzupełniające (gastronomia, transport, rekreacja, rozrywka itp.). 
Turystyka może pełnić również funkcję stymulującą i dotyczy tych gmin i powiatów, które postrzegają ją jako czynnik pobudzający lokalny rozwój społeczno-gospodarczy. Zdarza się, że obszary te nie były wcześniej traktowane jako destynacje turystyczne, ale dzięki pojawieniu się nowych funkcji stymulujących lokalną gospodarkę stają się stopniowo atrakcyjne dla ruchu turystycznego, a niekiedy stają się alternatywą dla obszarów turystyki masowej (Grabowska, 2016: 75-76).

Władze samorządowe lokalnego szczebla są głównymi podmiotami odpowiedzialnymi za rozwój lokalny, a gdy turystyka odgrywa stymulacyjną rolę rozwojową, za kreowanie lokalnej polityki turystycznej. Takie podejście wynika przede wszystkim z faktu, że turystyka staje się w wielu miejscach sposobem na tworzenie nowych miejsc pracy, a usługi turystyczne stają się produktami eksportowymi lokalnych gospodarek. Dlatego też w gminach i powiatach szczególne miejsce w zaspokajaniu potrzeb turystów zajmują podmioty prowadzące działalność gospodarczą w turystyce. Odpowiednie oddziaływanie władz lokalnych na postępowanie tychże podmiotów pozwala na realizację poszczególnych celów zawartych w lokalnych strategiach rozwoju. Oddziaływanie to może polegać na zachęcaniu do podejmowania aktywności gospodarczej w turystyce, w tym na wyborze określonego rodzaju działalności gospodarczej w tej dziedzinie, inwestycjach w infrastrukturę turystyczną, tworzeniu nowych miejsc pracy w branży turystycznej i współudziale w budowaniu i promocji lokalnego produktu turystycznego (Rapacz, Jaremen, 2009: 211-213).

W wielu gminach, powiatach i województwach turystyka - zarówno w aspekcie społecznym, jak i ekonomicznym - staje się istotnym czynnikiem rozwoju społeczno-gospodarczego, a zwłaszcza rozwoju lokalnego sektora usługowego. Efektem tego jest przyrost ilościowy i jakościowy infrastruktury turystycznej i paraturystycznej, która następnie wykorzystywana jest nie tylko przez turystów, ale i przez mieszkańców w ich codziennym życiu. Infrastruktura ta w istotny sposób podnosi poziom i jakość życia lokalnych społeczności, gdyż przyczynia się pośrednio, a czasami bezpośrednio, do zwiększenia dostępności infrastruktury komunalnej (gazowej, elektrycznej, telefonicznej, kanalizacji, drogowej itp.) (Szostak, 2011: 248-249).

Rozwój turystyki przyczynia się także do lepszego i bardziej racjonalnego zagospodarowania zasobów naturalnych i kulturowych. Społeczności lokalne uzyskują również większy dostęp do usług handlowych, medycznych, rozrywkowych itp. Bardzo często działanie władz samorządowych, polegające na opracowaniu strategii rozwoju turystyki i na aktywizacji turystycznej gminy lub powiatu (np. poprzez tworzenie nowych miejsc pracy czy punktów obsługi turystycznej), może być przejawem wzrostu znaczenia turystyki dla lokalnej gospodarki (np. dana gmina ewoluuje z gminy rolniczej, poprzez bycie gminą rolniczo-turystyczną, do gminy wyłącznie turystycznej. Jest to przykład zjawiska autonomizacji celów, tj. zmiany jednych celów rozwojowych na inne równie ważne cele, bazujące na zmianie znaczenia i sposobie wykorzystania swoich zasobów).

Niekiedy władze samorządowe potrzebują bodźca zewnętrznego do podjęcia tego typu działań. Może nim być aktywność partnera lub sąsiada zagranicznego (czasem wynikająca z transgranicznego położenia), który stara się o dofinansowanie swoich przedsięwzięć turystycznych, np. ze środków funduszy strukturalnych Unii Europejskiej. Inicjatorem lokalnych działań proturystycznych mogą być również krajowe organizacje turystyczne różnego szczebla. Dla wielu lokalnych decydentów turystyka staje się też ważna wtedy, gdy coraz bardziej zauważalne stają się sukcesy odnoszone w tej 
dziedzinie przez inne samorządy, nie tylko te konkurencyjne, ale przede wszystkim te, które mogą stać się wzorcem rozwojowym. Bodziec konkurencyjności regionalnej i niechęć do pozostawania w tyle przyczyniają się często do przyspieszenia działań aktywizujących władze samorządowe do rozwoju turystycznego (Szostak, 2004: 67-72).

Co istotne dla gminnych i powiatowych władz samorządowych, rozwój turystyki i realizacja inwestycji turystycznych sprzyjają również działaniom dywersyfikującym lokalną gospodarkę. Powinny one zostać poprzedzone inwentaryzacją zasobów naturalnych, kulturowych i turystycznych gminy lub powiatu. Inwentaryzacja ta pozwoli następnie przeprowadzić analizę SWOT takiego obszaru pod kątem turystycznym i pomoże wskazać kierunki dalszego rozwoju turystycznego tego regionu. Niewłaściwe byłoby inicjowanie działań proturystycznych, a następnie świadczenie usług turystycznych, które nie spełnią potrzeb turystów. Pożądane jest, aby władze samorządowe zachęcały lokalnych przedsiębiorców i społeczności do aktywnego angażowania się w działania prorozwojowe i proturystyczne. Brak chęci lub niezrozumienie problemu przez lokalnych przedsiębiorców może przyczynić się do porażki tego przedsięwzięcia. Działania proturystyczne w wielu gminach i powiatach powinny stanowić element długofalowej strategii rozwoju regionalnego i lokalnego.

Zarządzanie lokalną turystyką jako sektorem gospodarczym wiąże się z realizacją szeroko rozumianej polityki turystycznej jako zespołu ukierunkowanych działań i narzędzi (w tym również strategii i różnego rodzaju planów). Polityka turystyczna, jako pojęcie szersze niż zarządzanie, obejmuje nie tylko działania ściśle związane z turystyką, ale również takie, które mają jakikolwiek związek z rozwojem tego sektora i które są wykorzystywane w tymże zarządzaniu. Jest to więc zespół działań regulujących procesy mające miejsce w turystyce i z nią związane.

Istotą lokalnej polityki turystycznej jest m.in. kształtowanie lokalnego systemu podaży turystycznej. Głównym problemem jest wykreowanie lokalnych produktów turystycznych, które byłyby bezpośrednio kojarzone z określonym miejscem. Działania związane z tworzeniem produktów turystycznych powinny się wiązać z aktywnością władz lokalnych (w tym lokalnych organizacji turystycznych). Obszar turystyczny, np. gminę lub powiat jako produkt, można analizować na kilku poziomach. Tworzą je:

- dziedzictwo - zasoby obszaru niezwiązane genetycznie z rozwojem turystyki, istniejące od zawsze, przekazywane z pokolenia na pokolenie, ale tworzące tę część potencjału rozwojowego obszaru, dzięki któremu w ogóle możliwy jest rozwój turystyki, np. przyroda, kultura, historia, gospodarka, kapitał ludzki,

- infrastruktura - zasoby obszaru związane z rozwojem turystyki, uzupełniające elementy pierwotne, uatrakcyjniające ofertę turystyczną, np. baza noclegowa, gastronomiczna, paraturystyczna, a także różnego rodzaju inwestycje będące pośrednim efektem napływu turystów (poprawa dostępności komunikacyjnej regionu, muzea, wystawy, wydarzenia),

- wartość dodana - atrybuty obszaru przynoszące określoną satysfakcję psychiczną turystom, w przypadku braku unikalnego dziedzictwa czy infrastruktury umożliwiają odróżnienie obszaru od sąsiednich terenów, których oferta jest bardzo podobna lub wręcz identyczna (np. miejscowości nadmorskie), najważniejsze elementy symboliczne tworzą:

- aktualny wizerunek miejsca i funkcjonujące na jego temat stereotypy,

- pomysł na produkt, czyli główna idea spajająca wszystkie działania w zakresie turystyki na danym terenie, 
- elementy programu identyfikacji produktu: nazwa, logo, slogan reklamowy, dźwięk, zakres i kontekst działań promocyjnych,

- tożsamość marki - wyjątkowe wartości, cechy, które powinny być trwale kojarzone z obszarem, a docelowo mają stać się częścią wizerunku całego terenu,

- organizacja i zarządzanie - wszelkie struktury i działania pozwalające funkcjonować powyższym elementom jako produkt turystyczny (Stasiak, Włodarczyk, 2003: 26).

\section{PLANOWANIE JAKO FUNKCJA ZARZĄDZANIA NA POZIOMIE LOKALNYM}

Planowanie jest podstawową i pierwotną funkcją zarządzania, niezależnie od tego, czy dotyczy to podmiotów biznesowych (komercyjnych, głównie firm), czy też innego rodzaju podmiotów - głównie jednostek samorządu terytorialnego różnego szczebla. Planowanie, aby było skuteczne, powinno być bliźniaczo skorelowane z inną funkcją zarządzania, a mianowicie z kontrolą. Dlatego też każdy dobry i skuteczny plan powinien uwzględniać narzędzia weryfikacyjne, kontrolne lub wdrożeniowe, zanim rozpocznie się procedura wdrażania go w życie. Wiele strategii ma moduły monitorowania ich wdrażania, co ma w praktyce zwiększyć skuteczność osiągania przyjętych założeń. Jest to jeden z istotniejszych czynników determinujących realizację lokalnych strategii rozwoju turystyki (Głąbiński, Szostak, Zalewski, 2016).

Planowanie w swojej istocie podnosi skuteczność działania i racjonalizuje dalsze funkcje zarządzania (m.in. organizowanie). Szczególne znaczenie planowania jest widoczne w przypadku analizy różnych aspektów rozwojowych jednostek samorządu terytorialnego, w szczególności w gminach. Proces planowania w gminach ma różne przyczyny i funkcje. Z jednej strony władze lokalne planują działania lub określony rozwój, gdyż wymaga tego ustawa lub inne dokumenty prawne, a z drugiej strony - gminy, które chcą się rozwijać w sposób ukierunkowany, powinny planować metodę eksploatacji swoich zasobów, na bazie których zamierzają np. rozwijać jakieś formy gospodarowania lub aktywności gospodarczej (Szostak, 2016).

Na władzach gminy spoczywa obowiązek aktywnego sterowania różnymi procesami lokalnego rozwoju przede wszystkim przez działania regulacyjne, inicjujące, organizujące oraz stymulująco-rozwojowe. W związku z tym władze gminne powinny stosować nowoczesne narzędzia zarządzania (w tym strategicznego) oraz aktywnie oddziaływać na skalę i tempo rozwoju zawiadywanego przez siebie obszaru, m.in. przez skuteczne planowanie. Skuteczne zarządzanie wymaga stosowania koncepcji zarządzania strategicznego (m.in. opracowywanie strategii rozwoju lokalnego, strategii rozwoju konkretnej dziedziny gospodarki np. turystyki).

Dzięki skutecznemu i efektywnemu planowaniu w dziedzinie turystyki gmina może jak najlepiej wykorzystać własne walory i zasoby turystyczne w dłuższej perspektywie. Podstawą rozwoju turystyki jest właściwe wykorzystanie własnego (endogenicznego) potencjału. Działania strategiczne w kwestii turystyki pozwalają na kształtowanie turystycznych procesów rozwojowych gminy i rozwiązywanie zdefiniowanych problemów w długim horyzoncie czasu. Dzięki planowaniu strategicznemu gospodarki turystycznej gminy można uzyskać maksymalne wykorzystanie endogenicznych czynników lokalnego rozwoju (głównie walorów naturalnych i antropogenicznych) oraz miejscowych podmiotów gospodarczych i mieszkańców. Kluczowym aspektem przy tego typu działaniach jest stan wiedzy władz danej gminy na temat korzyści z rozwiązywania 
problemów rozwojowych w oparciu o usługi, w tym turystyczne, oraz determinacja w praktycznym stosowaniu procesu planowania (Ziółkowski, 2015).

Planowanie w praktyce działania władz lokalnych odnosi się do dwóch podstawowych płaszczyzn:

- płaszczyzny aspektów i zasobów twardych gminy, na które składają się m.in. kontrola kosztów, planowanie i alokacja zasobów (np. endogenicznych), wyznaczenie odpowiednich celów do realizacji, zapotrzebowanie na kapitał itp.; w większości przypadków strategie rozwoju turystyki odnoszą się do zagospodarowania tego typu zasobów będących w podsiadaniu gminy i znajdujących się na jej terenie;

- płaszczyzny aspektów miękkich gminy, w skład których wchodzi przede wszystkim funkcja motywująca, czyli plan dający motywację do działania (władzom lokalnym, odpowiedzialnym za wdrażanie planów osobom i organizacjom lokalnym, mieszkańcom gminy), zaspokajający potrzebę wysiłków i starań; sprawne działanie na poziomie lokalnym wymaga najczęściej skutecznego i odpowiedniego planu działania; gdy gmina chce się rozwijać w jakiejś sferze, powinna mieć plan, który najczęściej jest najlepszym motywatorem do działania; plan służy nie tylko do tego, aby osiągnąć zamierzone cele, ale również staje się narzędziem przetrwania w konkurencyjnym i coraz bardziej nieprzewidywalnym otoczeniu rynkowym (Jarmuż, Tarasiewicz, 2017: 192-204).

\section{CHARAKTERYSTYKA POTENCJAŁU ENDOGENICZNEGO GMINY MORYŃ JAKO PODSTAWA REALIZACJI TURYSTYCZNEJ FUNKCJI USŁUGOWEJ}

Gmina Moryń położona jest w południowo-zachodniej części województwa zachodniopomorskiego, na pograniczu Pojezierza Myśliborskiego i Równiny Gorzowskiej. Leży ona w granicach administracyjnych powiatu gryfińskiego i sąsiaduje z następującymi gminami: Cedynia, Chojna, Trzcińsko-Zdrój i Mieszkowice. Charakteryzuje się bogatymi zasobami środowiska przyrodniczego i kulturalnego. Gmina Moryń obejmuje 18 miejscowości oraz 9 sołectw: Gądno, Witnicę, Bielin, Stare Objezierze, Nowe Objezierze, Klępicz, Przyjezierze, Dolsko, Mirowo. Moryń jest siedzibą władz gminy. Brak zakładów przemysłowych oraz brak przekroczenia wartości dopuszczalnych dla dwutlenku siarki, dwutlenku azotu pyłu zawieszonego PM10 (wyjątkiem jest benzo(a)piren, którego wartość przekracza dopuszczalne normy) sprawia, że gmina jest ekologicznie czysta. Sąsiedztwo Cedyńskiego Parku Krajobrazowego wraz z mocno urozmaiconym krajobrazem polodowcowym sprawia, że Moryń i cała gmina należy według znawców tejże tematyki do najpiękniej położonych miast tej części Pomorza Zachodniego.

Moryń zachował średniowieczny układ urbanistyczny, pełen wieniec murów obronnych, domy ryglowe z XVIII i XIX wieku. Najcenniejszy obiekt architektury romańskiej na Pomorzu Zachodnim to granitowa bazylika z XII wieku. W 1874 roku w południowo-zachodniej części miasta dr Ch.F. Koch ufundował dom opieki dla dzieci, który funkcjonuje do dziś (przed zakładem wychowawczym postawiono popiersie fundatora).

Ślady przeszłości, i tej odległej z okresu średniowiecza, i nowszej z XIX i początku XX wieku, odnaleźć też można w większości wsi położonych w obrębie gminy. W Bielinie, Dolsku, Klępiczu, Mirowie, Przyjezierzu, Starym i Nowym Objezierzu, Witnicy zachowały się kamienne świątynie z XIII i XIV wieku. W Gądnie i Przyjezierzu przetrwały 
stare klasyczne siedziby rodów związanych z dziejami Morynia, a wraz z nimi duże parki, które zachowały się również w Bielinie, Witnicy, Mirowie i Przyjezierzu.

Gmina Moryń jest regionem o największej jeziorności w całym powiecie gryfińskim (49\% powierzchni gminy stanowią akweny). Ukształtowanie terenu jest silnie urozmaicone, co przy niewielkiej lesistości (27,3\% - po Gryfinie najmniej w powiecie) sprawia, że krajobraz jest bardzo bogaty w punkty widokowe (pięć). Na terenie gminy Moryń naliczono aż 52 pomniki przyrody (najwięcej w powiecie) i 32 pomnikowe głazy narzutowe. Gmina obfituje w cenne walory geologiczne i geomorfologiczne, związane z zachowanymi formami polodowcowymi i dużą liczbą głazów narzutowych. Większą część gminy obejmuje teren geoparku - rejonu, w którym szczególna uwaga skierowana jest na walory geologiczno-geomorfologiczne.

W samym Moryniu w ramach współpracy transgranicznej istniejącego geoparku „Kraina polodowcowa nad Odrą” funkcjonuje: aleja gwiazd plejstocenu (10 tablic przedstawiających ssaki epoki lodowcowej), centrum geoparku (odremontowany budynek obok ratusza miejskiego) wraz z wystawą prezentującą przeszłość geologiczną regionu, lapidarium olbrzymich głazów narzutowych zebranych z najbliższej okolicy.

Gmina Moryń jest rejonem występowania kamiennych budowli średniowiecznych (świątyń oraz budowli fortyfikacji miejskich w Moryniu). Spośród 10 zabytkowych kościołów w gminie 9 powstało w XIII i XIV wieku z kamieni polnych. Dwa z nich (w Moryniu i Dolsku) mają w portalu ciosy granitowe z zachowanym znakiem szachownicy. W gminie Moryń zanotowano także największą liczbę zachowanych (również jako ruina) założeń zamkowych, pałacowych i dworskich w całym powiecie (pięć obiektów - ruina w Przyjezierzu, w Bielinie, Witnicy, Gądnie i ruiny zamku w samym Moryniu).

Warto podkreślić, że gmina Moryń dość mocno promuje swoje walory kultury niematerialnej, tworząc szlak tematyczny związany z lokalnymi legendami (szlak legend moryńskich). Gmina ma największy z całego powiatu gryfińskiego zasób tradycyjnych opowiadań, legend i historii związanych z obiektami i miejscami (centralne miejsce zajmuje legenda o Raku, młodym morynianinie, który uratował miasto i zginął z rąk najeźdźcy, a w ciepłe, letnie noce wychodzi z jeziora pod postacią wielkiego skorupiaka; motyw z rakiem był wykorzystywany np. na przedwojennych pocztówkach). Dumą gminy Moryń jest jeden z najstarszych kościołów województwa zachodniopomorskiego - kościół pw. Świętego Ducha - romańsko-gotycka świątynia zbudowana według podań w miejscu dawnej świątyni Światowida. Dzięki temu, że Moryń uniknął zniszczeń w czasie II wojny światowej, zachował się w mieście średniowieczny układ urbanistyczny i prawie pełny obwód miejskich murów obronnych, które otaczają miasto kołem o średnicy około $300 \mathrm{~m}$.

Gmina Moryń ma długą tradycję turystyczną i dobrze zagospodarowaną przestrzeń. Znajduje się tu jeden hotel oraz siedem ośrodków i pensjonatów, jak również gospodarstwa agroturystyczne. Baza gastronomiczna reprezentowana jest przez osiem lokali o różnym standardzie i ofercie. Nad jeziorem Morzycko działają również: kąpielisko, miejsca wykorzystywane do kąpieli, wyciąg do wakeboardingu oraz wypożyczalnie sprzętu. Do bazy turystycznej zaliczyć także należy stadniny koni i ośrodki jazdy konnej (dwa obiekty). Przez teren gminy przechodzą dwa znakowane szlaki piesze i dwa rowerowe. Funkcjonują tu również szlaki tematyczne, w tym najważniejszy z punktu widzenia rozwoju turystycznego gminy - geologiczny, związany z geoparkiem, i tematyczny szlak legend moryńskich. 
Większość gminy Moryń, tj. około 80\%, leży w otulinie Cedyńskiego Parku Krajobrazowego, a pozostała część, tj. około 20\%, należy do samego parku. Dzięki temu gmina ma ponadlokalne i regionalne walory przyrodnicze. Gmina leży na zachodnim skraju makroregionu Pojezierze Zachodniopomorskie i mezoregionu Pojezierze Myśliborskie. Dominuje tu krajobraz morenowy ukształtowany przez ostatnie zlodowacenie.

Największym przyrodniczym skarbem gminy jest jezioro Morzycko, jedno z najgłębszych jezior w Polsce (58,5 m - kryptodepresja). Oprócz tego gmina obfituje w jeziora o średniej i małej powierzchni.

Obszar wokół Morynia cechuje urozmaicony krajobraz dzięki wzgórzom, jeziorom i malowniczym zabudowaniom wiosek. Centralnie położone, duże jezioro Morzycko tworzy wraz z otaczającymi wzniesieniami, lasami i zabudową Morynia malowniczy widok. Przed wojną była to miejscowość o charakterze uzdrowiskowym.

Pod względem geobotanicznym teren gminy zaliczany jest do krainy Pojezierze Pomorskie, okręgu Myśliborskiego (północna część gminy) i krainy: Pomorski Południowy Pas Przejściowy, okręg Brzeg Pradoliny Noteckiej (część południowa gminy). Położenie na granicy dwóch krain geobotanicznych daje ogromne bogactwo roślinne gminy. Spotykamy tu zarówno element atlantycki, jak np. kłoć wiechowata, lasy z dużym udziałem buka, jak i typowe bory sosnowe. Lasy tego typu nadają się do rekreacji i są stosunkowo odporne na antropopresję.

Jezioro Morzycko, o powierzchni lustra wody 342,7 ha, jest siedliskiem m.in. sielawy, ryby charakterystycznej dla jezior bardzo czystych. Duże obszary dna porastają rzadkie już zespoły lilii wodnych z grążelem żółtym, grzybieniem białym oraz bardzo rzadkim grzybieniem północnym. Dla ochrony najcenniejszych fragmentów tych zbiorowisk planowane jest uznanie ich za stanowiska florystyczne (w Moryniu, u ujścia rzeki Słubii i w Starym Objezierzu).

Rzeka Słubia to czysty, bystro płynący potok przepływający przez Morzycko, o czym świadczy występowanie tu pstrąga potokowego oraz rzadkiego gatunku krasnorostu: Hildenbrandia rivularis (hildenbrandia rzeczna). Koryto cieku porastają także kolonie słodkowodnych gąbek i mszywiołów. W założeniach Cedyńskiego Parku Krajobrazowego jest utworzenie tu rezerwatu przyrody.

Niezapomnianych wrażeń dla płetwonurków dostarczą podwodne łąki i ogromne, przypominające rafy koralowe kolonie gąbek występujące w południowej części Morzycka oraz na Jeziorze Bielińskim Dużym.

W gminie Moryń doskonałe warunki znajdą ornitolodzy, obserwatorzy i miłośnicy ptaków. Na południowym zachodzie gminy znajduje się wyjątkowo cenny kompleks śródleśnych jeziorek eutroficznych, projektowany rezerwat przyrody Łabędzin o powierzchni 11 ha. Swoje ostoje mają tu rzadkie gatunki ptaków, jak: bączek, wodnik, cyraneczka, bąk, perkoz, płaskonos, błotniak stawowy czy kureczka zielonka.

\section{STRATEGIA ROZWOJU GMINY MORYŃ DO 2022 ROKU JAKO NARZĘDZIE DZIAŁAŃ PROTURYSTYCZNYCH I KREOWANIA NOWYCH PRODUKTÓW USŁUGOWYCH ${ }^{1}$}

Jak wspomniano we wprowadzeniu do artykułu, jednym z najważniejszych narzędzi rozwoju lokalnego w oparciu m.in. o rozwój produktów turystycznych bazujących na endogenicznych zasobach stała się Strategia rozwoju gminy Moryń do 2022 roku,

\footnotetext{
${ }^{1}$ Podrozdział napisany na podstawie: Strategia ... (2019).
} 
której opracowanie w 2015 roku zleciły, a następnie wdrożyły ją gminne władze samorządowe. Strategia ta w znacznej mierze specjalizuje gminę Moryń jako gminę usługową z dominującą funkcją turystyczną, opartą na walorach jeziora Morzycko i innych dobrach przyrodniczych oraz kulturowych. Poprzednia strategia, tj. strategia rozwoju gminy Moryń z 2007 roku, za cel strategiczny stawiała wszechstronny rozwój gminy poprzez wykorzystanie miejscowych walorów krajobrazowo-kulturowych, bazy turystycznej, areału urodzajnych gruntów ornych oraz potencjału zintegrowanej społeczności. Gmina nie miała, jak obecnie, głównie charakteru turystycznego, ale przede wszystkim turystyczno-rolny, odnoszący się w zdecydowanej części do tradycji rolnych (dominujących przed 2007 rokiem). Na podstawie analizy dokumentów sprzed 2007 roku oraz dwóch strategii - tej z 2007 roku i obecnej - można zauważyć świadomą i ukierunkowaną ewolucję gminy Moryń i jej władz w sferze gospodarczo-usługowej od charakteru typowo rolniczego, poprzez turystyczno-rolny do usługowo-turystycznego, z dużym naciskiem na potrzeby tworzenia infrastruktury niezbędnej do świadczenia usług turystycznych opierających się na endogenicznym potencjale i wysokiej atrakcyjności turystycznej.

Strategia rozwoju gminy Moryń do 2022 roku wskazała kluczowe problemy rozwoju związane z turystyką, a które koncentrują się na dwóch kwestiach, tj. rozwoju gospodarczym i potencjale turystycznym. Niski poziom rozwoju gospodarczego objawia się przede wszystkim:

- niewystarczającą liczbą inwestorów turystycznych,

- brakiem mikroprzedsiębiorczości opartej na turystyce,

- niskim poziomem zamożności mieszkańców gminy,

- brakiem wiary w sukces biznesu turystycznego.

Niewykorzystany potencjał turystyczny gminy odnosi się do:

- funkcjonowania niewykorzystanych turystycznie i gospodarczo dawnych ośrodków turystycznych, gruntów proturystycznych,

- niewykorzystania w pełni potencjału obiektów historycznych,

- niepełnego rozwoju bazy turystycznej gminy i infrastruktury na podstawie zasobów przyrodniczych i kulturowych,

- występowania wysokiej sezonowości w lokalnej branży turystycznej (obsługa turystyczna koncentruje się głównie w miesiącach letnich),

- braku zintegrowanych działań zmierzających do kreacji markowych lokalnych i regionalnych produktów turystycznych.

Turystyka potwierdziła swoje strategiczne miejsce w rozwoju społeczno-gospodarczym gminy Moryń przede wszystkim w postaci umiejscowienia jej wizji i misji. Wizja gminy przedstawia się następująco: „Gmina Moryń to atrakcyjne miejsce do inwestowania i rozwijający się rynek pracy, dysponująca przyjazną infrastrukturą społeczną i techniczną, posiadająca utrwaloną pozycję na rynku usług turystycznych, stanowiących ważne źródło dochodów mieszkańców ceniących sobie wysoką jakość życia”. Z kolei misja gminy brzmi: „Wszechstronny rozwój gminy Moryń poprzez wykorzystanie miejscowych walorów krajobrazowo-kulturowych, bazy turystycznej oraz potencjału zintegrowanej społeczności gminy".

Zakładając, że władze gminy, realizując strategię rozwoju społeczno-gospodarczego, dążą do rozwoju gospodarki turystycznej, bazującej na potencjale walorów naturalnych i antropogenicznych (w tym kulturalnych), można określić kilka celów strategicznych w zakresie turystyki. Są to mianowicie: 
- wspomaganie rozwoju turystyki i promocja oferty turystycznej gminy,

- tworzenie szerokiej oferty turystycznej i współpraca w tym zakresie z ościennymi gminami,

- tworzenie i rozbudowa infrastruktury turystycznej i okołoturystycznej,

- instytucjonalne wspieranie rozwoju turystyki.

Na podstawie przeprowadzonej analizy SWOT (jako część analityczna strategii) można stwierdzić, że najmocniejszymi stronami gminy Moryń są:

- trwała ochrona wybitnych walorów przyrodniczych i krajobrazowych gminy w obszarze i otulinie Cedyńskiego Parku Krajobrazowego,

- posiadanie produktów turystycznych oraz walorów naturalnych i antropogenicznych o znaczeniu ponadgminnym, np. geopark, jezioro Morzycko.

Walory środowiska przyrodniczego oraz walory kulturowe i historyczne stanowią silną przesłankę rozwoju społeczno-gospodarczego gminy Moryń, w tym w zakresie preferowanej przez władze turystyki, w szczególności w obszarze realizacji strategii. Walory te powinny być wykorzystywane i odpowiednio zagospodarowane, jako stymulator rozwoju, np. w zakresie przyciągania inwestorów, rozwijania lokalnej przedsiębiorczości i sprzedawania produktów gminnych na zewnątrz (tj. promowanie eksportu turystycznego i aktywne przyciąganie turystów, wydłużanie sezonu turystycznego, stopniowe podnoszenie zamożności mieszkańców, kreowanie stałych i całorocznych miejsc pracy i zmniejszanie bezrobocia).

Z kolei najbardziej niepokojącymi, słabymi stronami o charakterze turystycznym, które uwidoczniły się w gminie Moryń okazały się:

- słabe lub niewystarczające zagospodarowanie turystyczne (np. jezior i rzek) dla rozwoju różnych form turystyki, w tym dekapitalizacja części obiektów turystycznych i kulturowych,

- sezonowość popytu i ruchu turystycznego.

Mimo istotnych walorów przyrodniczych i kulturowych Morynia oraz korzystnej konfiguracji przestrzennej ich rozmieszczenia - słabością obszaru jest również brak odpowiedniej bazy do rozwoju różnych form turystyki, zwłaszcza w rejonach o dużym potencjale przyrodniczo-kulturowym (okolice jeziora Morzycko). Oczywiście w wyniku rozwijających się procesów gospodarczych powstają pojedyncze obiekty świadczące wybrane usługi z tego sektora (noclegowe czy też gastronomiczne) - jednak pełne wykorzystanie turystyczne potencjału gospodarczego gminy Moryń jest nadal utrudnione.

Do najistotniejszych szans rozwoju społeczno-gospodarczego gminy Moryń zaliczyć można:

- rozwój współpracy gospodarczej i społecznej w obszarze przygranicznym i w aspekcie transgranicznym,

- dostępność funduszy strukturalnych Unii Europejskiej i z innych źródeł na rozwój społeczno-gospodarczy,

- rozwój alternatywnych, pozarolniczych źródeł utrzymania mieszkańców wsi (np. agroturystyka, produkcja i handel kulinariami),

- postępujący rozwój ekonomiczny regionów transgranicznych.

Natomiast najważniejszymi zagrożeniami, z jakimi należałoby walczyć i je niwelować, są:

- duże obciążenie gminy realizacją narzuconych odgórnie zadań własnych (brak środków na inne zadania, np. rozwój lokalnej gospodarki turystycznej), 
- występujący wśród mieszkańców mniejszych gmin i powiatów (najczęściej konserwatywnych, monogospodarczych) opór przed zmianami społeczno-gospodarczymi.

Przedstawiona analiza rozwoju turystycznego gminy Moryń wskazuje na znaczny potencjał rozwojowy gminy, zwłaszcza w obszarze gospodarki turystycznej. Moryń ma duży potencjał rozwojowy, w tym turystyczny (np. dzięki lokalizacji w strefie transgranicznej, dużemu zaangażowaniu władz lokalnych w rozwój turystyki i poszukiwaniu dróg rozwoju), przy czym widoczny jest pewien niedorozwój w zakresie funkcjonowania na terenie gminy infrastruktury turystycznej, przede wszystkim bazy noclegowej oraz gastronomicznej. Niedorozwój ten, jeśli nie będzie niwelowany, może doprowadzić do pogłębienia się różnic między silnymi i słabymi stronami, z przewagą tych drugich.

Wiele słabych stron wynika z niedorozwoju infrastruktury ogólnej. Posiadanie określonych walorów turystycznych (np. jezioro Morzycko, parki krajobrazowe) i antropogenicznych (historycznych i kulturowych) oraz atrakcyjna lokalizacja całej gminy (strefa przygraniczna) nie stanowią jeszcze o odniesieniu sukcesu społeczno-gospodarczego. Bardzo ważne są inwestycje drogowe, zwiększenie dostępności komunikacyjnej oraz kreowanie działań proturystycznych, których efektem jest powstawanie infrastruktury turystycznej i sportowej typu szlaki rowerowe, punkty widokowe, punkty informacji turystycznej. Końcowym elementem powinny być działania komercjalizujące w postaci markowych produktów turystycznych promowanych w zintegrowany sposób.

Zaplanowane na najbliższe lata działania proturystyczne w gminie Moryń mają doprowadzić do uzyskania infrastruktury tworzącej kulturowy produkt turystyczny oraz wprowadzić ów produkt do obrotu gospodarczego (jego skomercjalizowanie poprzez m.in. rozwój usług turystycznych). Działania bezpośrednio związane z produktem swoim zasięgiem obejmują historyczny obszar miasta, warowny gród z podzamczem i łączący je trakt. Tworzą potencjał infrastrukturalny i instytucjonalny produktu. Największa kosztowo, a jednocześnie niezbędna dla produktu jest rekonstrukcja historyczna grodu zamkowego i podzamcza, która warunkuje wyznaczenie szlaku dydaktycznego, stanowiącego oś produktu.

Działania pośrednie porządkują przestrzeń wokół produktu i tworzą jego związki z innymi produktami turystycznymi. Wszystkie są wobec siebie komplementarne. Realizowane będą przez różne podmioty: lokalny samorząd, gestorów usług turystycznych, gestorów usług okołoturystycznych. Część zadań, szczególnie tych związanych z przygotowaniem kwater dla turystów w mieście w obrębie murów, może być realizowana przez właścicieli nieruchomości (mieszkańców). Działania związane z promocją i obsługą produktu tworzą możliwości włączenia w proces tworzenia i obsługi produktu lokalnych stowarzyszeń. Działania związane z rewitalizacją tkanki miejskiej i porządkowaniem przestrzeni architektonicznej realizowane będą we współpracy $\mathrm{z}$ uczelniami.

\section{PodsumoWANIE}

Rozwój i planowanie turystyki na poziomie lokalnym, zwłaszcza gminnym, wymaga od lokalnych władz myślenia i działania nieoperacyjnego, tj. nie z sezonu na sezon, ale w dużej mierze strategicznego, czego przykładem powinien być dobrze opracowany plan rozwojowy gminy lub też poświęcona turystyce strategia (Szostak, 2017). Proces długoletniego planowania (zwłaszcza o charakterze strategicznym, jak pokazała gmina 
Moryń) w obszarze rozwoju lokalnej usługowej gospodarki turystycznej pozwala na wskazanie wielu praktycznych korzyści i efektów dla poszczególnych gmin, a mianowicie pozwala na:

- identyfikację podstawowych oraz kluczowych problemów rozwojowych lokalnych gospodarek i społeczności;

- identyfikację strategicznych turystycznych potencjałów rozwojowych danej gminy;

- dokładną inwentaryzację turystycznego potencjału endogenicznego gminy (jakie konkretnie zasoby ma dany obszar i do czego mogą służyć);

- identyfikację kluczowych turystycznych szans i zagrożeń rozwojowych;

- skoordynowanie i ukierunkowanie działań wszystkich uczestników procesów rozwojowych gminy (władz, społeczności i lokalnego biznesu) wokół powyższych uwarunkowań i wyznaczonych celów do realizacji;

- wskazanie narzędzi niezbędnych do realizacji przedsięwzięć turystycznych uznanych za najważniejsze dla rozwoju lokalnego;

- koordynację w czasie i przestrzeni owych przedsięwzięć poprzez identyfikację głównych centrów rozwojowych i przypisanie im czasowych ram realizacji;

- integrację tej dominującej części społeczności lokalnej wokół wizji i szczegółowych koncepcji rozwoju lokalnego oraz wspólnych działań na jej rzecz (Sztando, 2015: 106-107).

Dlatego też opracowywanie i wdrażanie lokalnej usługowej strategii rozwoju opartej na turystyce powinno przyczyniać się do:

- wskazania obszarów działalności turystycznej, zapewniających największe lokalne korzyści społeczno-gospodarcze,

- zrozumienia, dlaczego różne inicjatywy w różnych obszarach działalności turystycznej przyniosły sukces rynkowy lub niepowodzenie,

- wskazania, jakich kwalifikacji i zasobów endogenicznych brakuje na lokalnym rynku turystycznym lub są one niewystarczające,

- wskazania grup docelowych turystów, o których najbardziej trzeba się troszczyć, i którzy będą beneficjentami rozwoju lokalnego turystycznego produktu usługowego,

- tworzenia lokalnych produktów turystycznych na bazie potencjału endogenicznego (Szostak, Zalewski 2017).

Wszystkie działania związane z planowaniem rozwoju lokalnego produktu turystycznego wpływają bezpośrednio na wykorzystanie potencjału endogenicznego (głównie kulturowego i przyrodniczego), którego różnorodne zasoby przyporządkowują jednemu celowi, jakim jest rozwój turystyczny gminy, i w innowacyjny sposób przekształcają je w spójny, jednorodny produkt usługowy. Mimo tego, że gmina bezpośrednio nie świadczy usług turystycznych, to jednak może aktywnie współuczestniczyć w oferowaniu produktu turystycznego obszaru (np. poprzez planowanie i tworzenie niezbędnej gminnej infrastruktury turystycznej) i wpływać na ruch turystyczny, co powinno wywoływać określone konsekwencje dla lokalnego życia społeczno-gospodarczego mieszkańców, tj. tworzenie miejsc pracy (Majewska, 2012: 36).

Żeby takie działanie było skuteczne, potrzebne jest właściwe planowanie na poziomie centralnym, tj. gminnym, a niekiedy również powiatowym i wojewódzkim. Jak pokazuje praktyka, wiele gmin planuje swój rozwój, opracowując, a następnie wdrażając strategię rozwoju społeczno-gospodarczego z turystyką uwzględnioną w misji 
(przykład gminy Moryń) lub decyduje się na opracowanie konkretnej strategii rozwoju turystyki (przykład powiatu gryfińskiego czy też gminy Karlino).

Podsumowując, można stwierdzić, że na przykładzie gminy Moryń widoczne jest określone i ukierunkowane działanie proturystyczne, którego celem jest:

- w pełni wykorzystać istniejący potencjał w postaci wybitnych walorów przyrodniczo- krajobrazowych gminy (głównie jezioro Morzycko);

- w nowy sposób i w pełni wykorzystać potencjał dziedzictwa kulturowego gminy;

- w pełni wykorzystać potencjał tkwiący w zbieżności charakterów istniejących i planowanych do utworzenia ofert turystycznych i możliwości zbudowania przy współpracy kilku podmiotów - dużego produktu turystycznego, który będzie tworzył wewnętrzne impulsy rozwoju dla gminy;

- w pełni wykorzystać potencjał wynikający z powiązań z innymi produktami turystycznymi o charakterze regionalnym, zlokalizowanymi w sąsiedztwie (m.in. trasa rowerowa pojezierna/tysiąca jezior, szlak samochodowy zachodniopomorskie pojezierza), co będzie tworzyło dodatkowe, zewnętrzne impulsy rozwoju dla gminy i regionu.

Budowa usługowego produktu turystycznego, w kontekście powyższych uwarunkowań i związków, w znaczący sposób może przyczynić się do pobudzenia społeczno-gospodarczego gminy i regionu oraz zwiększać potencjał powstawania nowych miejsc pracy i prowadzić do poprawy dostępności rynku pracy, zarówno w skali lokalnej, jak i w regionie województwa zachodniopomorskiego. Działaniom stricte turystycznym muszą jednocześnie towarzyszyć inne działania infrastrukturalne, mające wpływ na jakość prowadzenia działalności turystycznej na terenie gminy (np. gospodarka wodno-ściekowa, lokalne drogi).

\section{Literatura}

\section{References}

Głąbiński, Z., Duda, T., Szostak, D. (2017). Strategia rozwoju turystyki dla gminy Karlino do 2025 roku. Karlino.

Głąbiński, Z., Szostak D., Zalewski, T. (red.) (2016). Strategia rozwoju turystyki na poziomie lokalnym. Przykład powiatu gryfińskiego. Warszawa: CeDeWu.

Grabowska, A. (2016, 15 marca). Lokalna gospodarka turystyczna a rozwój regionów. Pozyskano z www.ue.katowice.pl

Jarmuż, S., Tarasiewicz, M. (2017). Alfabet mitów menadżerskich, czyli o pułapkach bezrefleksyjnego działania. Sopot: Gdańskie Wydawnictwo Psychologiczne.

Majewska, J. (2012). Rola samorządu terytorialnego w kształtowaniu funkcji turystycznej gminy. Poznań: Wydawnictwo Uniwersytetu Ekonomicznego w Poznaniu.

Rapacz, A., Jaremen, D.E. (2009). Oddziaływanie samorządu lokalnego na rozwój turystyki i branży turystycznej w wybranych gminach powiatu jeleniogórskiego. Prace Naukowe Uniwersytetu Ekonomicznego we Wrocławiu, 46.

Stasiak, A., Włodarczyk, B. (2003). Produkt turystyczny - miejsce. Turyzm, 1. Za: J. Kaczmarek, A. Stasiak, B. Włodarczyk. (2005). Produkt turystyczny. Pomysł - organizacja-zarzadzanie. Warszawa: Polskie Wydawnictwo Ekonomiczne.

Strategia rozwoju gminy Moryń na lata 2016-2022 (2019, 15 kwietnia). Urząd Miejski w Moryniu. Pozyskano z http://bip.moryn.pl/strony/5600.dhtml

Szostak, D. (2004). Rola lokalnej polityki turystycznej w tworzeniu i promocji markowych produktów turystycznych. W: A. Panasiuk (red.). Markowe produkty turystyczne. SzczecinNiechorze: Katedra Zarządzania Turystyką Uniwersytetu Szczecińskiego.

Szostak, D. (2011). Finansowanie inwestycji turystycznych - wybrane zagadnienia. Zeszyty Naukowe Uniwersytetu Szczecińskiego, 666, Problemy Zarządzania, Finansów i Marketingu, 19. 
Szostak, D. (2016). Strategia rozwoju turystyki jako narzędzie kreowania lokalnej marki turystycznej na przykładzie powiatu gryfińskiego. Marketing i Zarządzanie, 4(45).

Szostak, D. (2017). Czynniki endogeniczne gminy jako podstawa rozwoju przestrzeni turystycznej na przykładzie gminy Moryń. Marketing i Zarządzanie, 1(47).

Szostak, D., Zalewski, T. (2017). Tworzenie lokalnych produktów turystycznych na bazie potencjału endogenicznego na przykładzie gminy Moryń. Roczniki Chojeńskie, 9.

Sztando, A. (2015). Współczesne bariery zarządzania strategicznego rozwojem lokalnym w Polsce. Nauki o Zarządzaniu, 4(25).

Tokarz, A. (2003). Ekonomika usług. Szczecin: Wydawnictwo Naukowe Uniwersytetu Szczecińskiego.

Witkowski, K., Starościc, D. (2008). System infrastruktury społecznej gminy. Sulechów: Instytut Prawa i Administracji Państwowej Wyższej Szkoły Zawodowej.

Ziółkowski, M. (2015) (2018, 24 kwietnia). Strategiczne zarządzanie rozwojem gminy. Pozyskano z pressto.amu.edu.pl

Daniel Szostak, dr, Uniwersytet Szczeciński, Instytut Geografii Społeczno-Ekonomicznej i Gospodarki przestrzennej, Zakład Turystyki i Rekreacji. Zainteresowania badawcze: ekonomika turystyki, strategie rozwoju turystyki, hotelarstwo, planowanie w turystyce, finansowanie turystyki, rozwój lokalny i regionalny, turystyka w gospodarce przestrzennej, zakładanie i prowadzenie działalności gospodarczej, funkcjonowanie przedsiębiorstwa turystycznego, zarządzanie ludźmi, komunikacja interpersonalna, skuteczne metody poszukiwania pracy, aktywność proprzedsiębiorcza studentów oraz osób bezrobotnych.

Daniel Szostak, PhD. Research interests: tourism economics, tourism development strategies, hotel management, tourism planning, tourism financing, local and regional development, tourism in spatial economy, establishing and running a business, tourism company operation, HR management, interpersonal communication, effective job search methods, pro-entrepreneurial activity of students and the unemployed.

ORCID: 0000-0002-2912-2672

\section{Adres/address:}

Uniwersytet Szczeciński

Wydział Nauk o Ziemi

Instytut Geografii Ekonomicznej i Gospodarki Przestrzennej

Zakład Turystyki

ul. Mickiewicza 16, 70-383 Szczecin, Polska

e-mail: daniel.szostak@usz.edu.pl 